Article

\title{
Qawwali Routes: Notes on a Sufi Music's Transformation in Diaspora
}

\author{
Sonia Gaind-Krishnan \\ Department of Music, New York University, New York, NY 10003, USA; sfg229@nyu.edu
}

Received: 10 October 2020; Accepted: 5 December 2020; Published: 21 December 2020

\begin{abstract}
In recent years, alongside the concurrent rise of political Islam and reactionary state policies in India, Sufism has been championed as an "acceptable" form of Islam from neoliberal perspectives within India and the Western world. Sufism is noted as an arena of spiritual/religious practice that highlights musical routes to the Divine. Among Chishti Sufis of South Asia, that musical pathway is qawwali, a song form that been in circulation for over seven centuries, and which continues to maintain a vibrant sonic presence on the subcontinent, both in its ritual usage among Sufis and more broadly in related folk and popular iterations. This paper asks, what happens to qawwali as a song form when it circulates in diaspora? While prominent musicians such as the Sabri Brothers and Nusrat Fateh Ali Khan exposed audiences in the West to the sounds of qawwali, in recent years, non-hereditary groups of musicians based in the US and UK have begun to perform songs from the qawwali repertoire. In the traditional setting, textual meaning is paramount; this paper asks, how can performers transmute the affective capacity of qawwali in settings where semantic forms of communication may be lost? How do sonic and metaphorical voices lend themselves to the circulation of sound-centered meaning? Through a discussion of the Sufi sublime, this paper considers ways sonic materials stitch together the diverse cloth of the South Asian community in diaspora.
\end{abstract}

Keywords: sound studies; qawwali; Sufism; diaspora; voice

\section{Introduction: Qawwali on the Edges of Empire}

Qawwali holds a certain cache in the South Asian consciousness that echoes across borders, percolating through the capillaries of diasporic networks; it is an eminently transreligious musical genre, even while firmly rooted in the Chishti Sufi practice of the subcontinent. It has held its sway in the diaspora as a vehicle for the expression of love, both worldly and Divine, and retains resonances with Bhakti musicality and ideology, which allow its embrace even in the current era of Hindutva governance within India. It was, without question, Nusrat Fateh Ali Khan (NFAK) that made the most lasting impressions on the international soundscape, although he was not the first to bring the sounds of qawwali to the outposts of postcolonial empire. His musical works are the seed from which diasporic developments in the qawwali listening space have sprung.

South Asian Sufism has registered on the international soundscape, audibly and materially, in the form of the qawwali voice. There is hardly a diasporic South Asian, of the generation coming of age in the World Music era, ${ }^{1}$ who would not immediately recognize Nusrat Fateh Ali Kahn's voice-from the

1 This is broadly the period between the mid-80s and the 2000s, when capitalism reached the pinnacle of its globalization phase; critiques of world music as a category include its celebratory multiculturalism and neocolonialist stance. This perspective divides the world in categories of the West and the Rest, lumping diverse cultures and practices around the world into a hegemonic, spicy stew of Otherness. 
staggering quantity of recordings of traditional qawwali performances he made during his career, ${ }^{2}$ his vocal cameos in film soundtracks Bolly to Hollywood, and collusions of his voice with Western musicians, notably Eddie Vedder of Pearl Jam and guitarist Michael Brook-his sound is unlike any other singer, living or memorialized. I emphasize voice here, rather than the totality of the qawwali ensemble, because while there is a $p a k k a^{3}$ traditional group format, and a certain expectation for the qawwali sound, as it has traveled around the globe through bearers of tradition then in torrents of media distribution, certain sonic signifiers of the genre have been destabilized. The qawwali voice, however, holds fast to its aesthetic ideal. This sound reverberates across the vast distances that intervene between sites of origin and transnational locations, a voice rich with sonic detail and textured timbres; qawwali voices are heard as lived, with a certain grain, as Barthes famously noted, of "the body in the voice as it sings" ${ }^{\prime 4}$.

Since first hearing qawwali in the 1990s, as an element of Real World Studios' efforts, ${ }^{5}$ and then remixed into transcendental dance tracks spun by deejays such as Cheb i Sabbah in the desi ${ }^{6}$ club scene in San Francisco of the same era, I have been sitting with the following questions: how does qawwali mean ${ }^{7}$ to transnational, diasporic audiences? How does it create an impression on the listener, even as they may not grasp the particular depth of semantic content, couched in the texts of qawwali songs? ${ }^{8}$ Are they impacted instead on some other level of listening-affectively, bodily, immediately? What about the ethical and/or religious disposition of both performers and listeners engaged in hearing this Sufi music? Once lifted from its originary context, what aesthetic and ethical possibilities are there for a music such as qawwali? Inhering in its sound, there is a certain driving force; I wonder aloud, in this paper, what transformations can the music endure while still retaining its capacity to affect the listener?

In her experiential examination of the meaning-feeling nexus within sarangi performance practice in North India, Qureshi (2000) notes the following problematic: "Often ... the significance of musical sound has been ethnographically asserted but interpretively ignored, effectively placing sound outside the purview of anthropology" (p. 806). The material of sound is a reservoir for interpretive analysis ripe with possibility. Since Qureshi's article was penned, the field of Sound Studies has made its mark on the way we do work in ethnomusicology; we have since become much more attentive to sound itself, which is generative of a certain sort of meaningfulness (Eisenlohr 2018). This study synthesizes data gathered through a combination of ethnographic approaches including interview, digital ethnography, in-place ethnography at the site of the Nizamuddin dargah (shrine) in Delhi, India, and incorporates autoethnographic experiential data; it aims to affirm the opportunities offered by a close reading of sonic material as an interpretive device. The question remains whether interpretation, as a text-orientated, poststructuralist endeavor, is still the goal.

2 Traditionally, qawwals are born into and are trained as members of hereditary collectives; this is true of Nusrat's lineage. Although he performed in shrine settings, NFAK was most recognized outside of Pakistan from his work in the concert setting; he developed a style of qawwali that is identifiably influenced by the virtuosic improvisatory techniques of Hindustani classical music practices. Along with the Sabri Brothers, he was one of the innovators in this regard, and still is considered a supreme qawwal, Shahensha-e-qawwali (king of kings of qawwals).

3 According to the Oxford Dictionary of Hindi, pakka has a range of significations including "cooked" or "ripe"; it also has the connotation of "precise," "authentic," and in a musical context, "classical."

4 (Barthes 1977). For more on the relationship between embodiment, gesture and voice see Rahaim (2012). For the role of the body in the cultivation of Sufi ascetic practices, see Saniotis (2012).

5 Peter Gabriel's "world music" label Real World Records brought a number of international artists to the attention of British and American audiences; problematics associated with the construction of a single, hegemonic category of music encompassing the range of human expression across the globe were debated in the ethnomusicology of the 90s and 2000s. See, for example, Erlmann (1996), Feld (1995), Slobin (1992), Stokes (2003).

6 Desi means "of the land" or desh; refers to people of South Asian (primarily Indian, Pakistani, and Bangladeshi) origin.

7 Qureshi's article "How Does Music Mean?" explores the capacities of sensorial ethnography to open up affective channels of meaning-making. "My goal" she says, "is to expand the meaning-feeling sensorium from the discursively mediated to the materiality and aurality of music itself" (Qureshi 2000, p. 814).

8 In her seminal ethnographic study of the qawwali practice at the Nizamuddin dargah (shrine) in Delhi, India, Qureshi (1986) emphasizes the centrality of texts over sounds as vehicles for the communication of content. 


\section{The Politics of Sound and the Sufi Sublime}

In recent decades, alongside the concurrent rise of political Islam and reactionary state policies in India, Sufism has been championed as an "acceptable" form of Islam from neoliberal perspectives within India and the Western world. ${ }^{9}$ Sufism is noted as an arena of spiritual/religious practice that highlights musical routes to the Divine. Among Chishti Sufis of South Asia, that musical pathway is qawwali, a song form that has been in circulation for over seven centuries, and which continues to maintain a vibrant sonic presence on the subcontinent, both in its ritual usage among Sufis and more broadly in related folk and popular iterations.

I began to think about this article in conversation with Texas-based qawwali singer Sonny Mehta of Riyaaz Qawwali, who mentioned in passing that his qawwali party had been invited to perform at an event honoring Indian and American heads of state during their visit to Houston, TX in 2019. While the group was unable to accept due to a prior engagement, ${ }^{10}$ it struck me as curious that the current Indian leader, who is known to lean toward a form of nationalist politics that has caused harm to Muslim communities within India, would have, during a sojourn to a significant site of South Asian diasporic settlement, been offered a form of entertainment rooted in the Muslim culture of the subcontinent. The irony of the stance vis-à-vis the Indian leadership—-prejudice at home, (appearance of) tolerance abroad-was difficult to overlook.

Within India, Sufi sites have long been held as heterogenous zones; while the piety of dedicated Sufis has a clear intent and orientation, dargahs (shrines) are generally welcoming spaces. Qawwali music, even as it arises from a specific set of practices, has resonances that exceed the borders of its intended use. Still, its identity is not in doubt; Qureshi notes that

non-Muslim listeners, especially those within the Hindi-Urdu-Panjabi language area, have a clear, if generalised, familiarity with qawwali as a distinctively devotional musical genre with a distinctly Muslim identity, rooted in religious practice, but also extending into the secular domain-in the Indian sense of what I prefer to call spiritual cosmopolitanism (Qureshi 1999, p. 66).

While there is a certain sort of interculturalism associated with the genre, the identification of qawwali as devotional and Muslim is generally clear among North Indian listeners. The spiritual cosmopolitanism Qureshi detects is characteristic of Sufi cultural spaces in the contemporary transnational mediascape.

Manuel (2008) points to what he calls the "Sufi vogue" in India in the 1990s-early 2000s, a trend which has heightened the appeal of Sufi-oriented art forms-including those popular culture and fusion projects that depart from the modes of comportment typical of the adab ${ }^{11}$ of Sufi cultural milieus-to middle class Indians of a range of political and religious identifications. Manuel observes that "the Sufi music movement can be seen from a variety of analytical perspectives, including as a local efflorescence of a global Sufi music fad, a revival of a hoary Indian tradition of pluralism and tolerance, or a bourgeois appropriation of a subaltern idiom" (p. 378). Within India, although the contributions to, and practice of, qawwali is largely syncretic, ${ }^{12}$ it retains its identification as a Muslim,

9 Funes (2016) explores the relationship between neoliberal economic policy and the individualizing tendencies of New Age spirituality within contemporary Western societies; I would suggest the appeal of Sufi expressive forms to both Western and South Asian audiences is an aspect of this tendency. This formulation, however, leaves out the complexity of ways Sufi sites have been targeted by fundamentalist groups in Pakistan, which at writing has included over 200 casualties since 2005. See Rana (2008) for an overview of the political implications of the extremist vs. Sufi debate in contemporary Pakistan.

10 The group was also invited to perform at an event held in protest of these visits; Riyaaz was unable to accept either invitation, as they were attending an awards reception at the Indian Cultural Center (ICC) in Milpitas, CA at the time. Their political orientation is resolutely inclusive; as such, they tend to steer clear of events of a partisan nature. They have noted, however, that recent forms of xenophobia, both within the South Asian and broader American communities, have negatively impacted their sustainability as a performing arts group.

11 Adab refers generally to respectful social etiquette. It is also a way of greeting among South Asian Muslims.

12 Manuel further notes that "in terms of style and structure, there are no distinctively Muslim aspects of qawwali, which freely or loosely uses melodies based on Hindustani rags, as well as tunes associated in other contexts with Hindu occasions; 
and Sufi, musical genre. Rozehnal elaborates, delineating the spaces between the traditional qawwali form and its popular iterations:

According to Chishti Sabiris, it is the combination of makan, zaman, and ikhwan ${ }^{13}$ that transforms the musical assembly into a sacred space. The careful attention to atmosphere and audience, they insist, distinguishes the closed, private performance of the Chishti Sabiri mahfil-i sama' from the daily, public gatherings for Qawwali at Sufi shrines throughout Pakistan. Disciples highlight these elements when comparing sama' with the pop-star Qawwali of the global recording industry as well. Their criticism of popular Qawwali is that it reduces mass-produced music to a form of commercialized entertainment that is often insensitive to the Sufi tradition. Sama', by contrast, constitutes a carefully choreographed technology for the enrichment of a Sufi's inner, spiritual development. Accessible exclusively to an elite cadre of disciples (murids) under the supervision of a teaching shaykh, the performance of sama' is always governed by strict rules of comportment (Rozehnal 2007, p. 664).

Sama', the spiritual listening practice of Sufis, is the site where the intent of qawwali, as a musical form and as a repertoire of musical works, reaches its fullest potential. Even as we locate the genre, however, we must caution ourselves not to let the figure of qawwali be rendered a stagnant thing; it has been in a state of fluidity since it was first sung - new poetry has been set to evolving melodic and rhythmic structures, improvisatory techniques have been incorporated, and instrumentation has shifted over time. ${ }^{14}$ While there are debates over limiting the streams of influence and maintaining the purity of the genre, from my reading, its impact within the diaspora is much like a pebble in the pond: there is a clear context from which resonances ripple outward. Those resonances have material effects; they contribute to shaping identities based on listening practices and, therefore, in material ways, they matter. While authenticity, stated or implied, has long been a core concern for ethnomusicology, in this paper, I would like to shift the focus toward questions of sonic fidelity, as I have come to view the imperative of preservation of cultural practices as untenable in a media-dominated environment that is changing as rapidly as the present one is. At this point in time, when anxieties related to the impact of sound-related technological developments are passé, ${ }^{15}$ perhaps it would be of some benefit if we turned our analytical lens toward questions related to sonic fidelity instead: In what ways do performers attend to and creatively mobilize sonic figures ${ }^{16}$ within diasporic settings? Could it be that the focus on originals causes us to miss simultaneous and important cultural developments?

Within diasporic sites, during the backlash against Muslim populations in the wake of the events of 9/11 in the US and 7/7 in the UK, a narrative emerged that depicted Sufism as an "acceptable" form

the qawwal-bacche, for example, sing songs set to the standard melody in rag Kafi, in dipchandi tal, associated with the Hindu vernal Holi festival, with texts speaking of Nizamuddin Auliya himself playing Holi" (Manuel 2008, p. 381). The cultural space from which contemporary qawwali arises is characterized by hybridity. Still, I'd argue that because the music is intended for sama', for spiritual listening in accordance with the tenets of Islam, while there may be no distinctive musical characteristics of qawwali that define it as Muslim, there are other contextual factors that confirm it as such (Lewisohn 1997).

13 Quoting the Sufi theorist Junayd of Baghdad (d. 910), Rozehnal (2007) relays the three requirements for the efficacy of sama' (Sufi listening assembly): makan or place, meaning a secluded site; zaman, time, meaning when no other duties are pressing; and ikhwan, companions, meaning listening should be performed along with others who are similarly seeking God.

14 The harmonium, for example, now a defining feature of the qawwali party, is a mid-19th century invention, while qawwali itself is said to have been in practice for at least seven centuries. See Rahaim (2011) for an insightful discussion of the politics related to harmonium adoption in post-colonial India.

15 See, for example, Weidman (2006) who discusses anxieties related to recording technologies and commercialization brought on by the recording industry in 20th c. India. Also, Qureshi (1999) notes, "In South Asia, even the most exclusive student of unmediated music-making cannot avoid a mediated public soundscape that may well transmit the music being studied over loudspeakers, radios, televisions, and cassette players. This is certainly the case for qawwali, a musical genre which is firmly embedded in Sufi practice, but is also widely recorded and media-disseminated for as long as the life of the Indian record industry itself" (p. 63).

16 I'm thinking here of the sort of "figure of sound" that Eidsheim discusses in Sensing Sound (Eidsheim 2015). The figure of sound is the result of processes of ossification which render the fluid dimensions of musicality static: "Certainty regarding a given sound and its meaning relies on the premise that a thick sonic event may be reduced to a static one, and in the process of this reduction we identify an object, a stable referent" (p. 2). Within these figures, meaning inheres. As they are split from sources and travel, these figures may help to shape the meaning conveyed in diasporic expressive arts. 
of Islam vis-à-vis the idealized secular form of governance practiced in the West. This narrative was shaped around the distinction between "Bad Muslims"17, anti-modernist, anti-“freedom" extremists influenced by Wahhabi and Salafi leanings, and the lighter side of Islam, Sufism, which has been perceived as iconic of tolerance and multicultural grace, ${ }^{18}$ Sufism in the Western world has come to function as an emblem of a sort of Islamic practice that values the unorthodox and the expressive, with particular emphasis on musical and other art forms. Sufism and its cultural manifestations were stamped with approval by the West, commodified and distributed, and shaped into yet another product of the culture industry.

Similarly, within India, culture industry representations of "Good Muslims" in Bollywood films have frequently been rendered on-screen through qawwali performances; although these often depart significantly from the traditional sonic form of qawwali, they are used onscreen for their representational value, and function as sites upon which political and social identities are negotiated. Sundar (2017) notes,

The settings and song situations of these more contemporary qawwalis emphasize two ideas. First, these songs render Sufism the "good" kind of Islam, tolerant and hip, sanctioned by Hindi cinema and by such venerated figures as Nusrat Fateh Ali Khan and A. R. Rahman. My reading dovetails with Peter Manuel's insight that the elite in India has embraced Sufi performances as a way to push back against the Hindutva-ization of the public and political sphere (p. 147).

Much like the Bollywood representations of qawwali, Western diasporic musical renditions retain certain significations which together form what I call the Sufi sublime (cf. Vajpeyi 2009). The Sufi sublime is an imaginary informed by Western ideas about Islam, on the one hand, and strategies of marketing outfits and powerhouses of cultural production, on the other. In the wake of rising forms of religious extremism-Christian, Hindu, and Muslim included-intolerance of various shades has been seeping into societies worldwide; in places where staid forms of rationalism have been dominant, populations have recently been inundated by a litany of other "isms": tribalism, nationalism, and fundamentalism among them. ${ }^{19}$

The Sufi sublime is something of a cultural mashup, incorporating decontextualized ideas and practices in a manner characteristic of the New Age; the Sufi sublime combines diverse elements such as Rumi's poetry, qawwali and other Sufi musics, and yoga as a form of personalized spiritualism; this sort of utilitarian montage has characterized the spiritual landscape of neoliberal modernism. This idea has a definite use value in its circulation; salient is the certainty that the category of "the sacred" functions in opposition to the secular and that these categories co-constitute one another. Furthermore, the content of "the sacred" is often quite far removed from the religious setting from which it was extracted. The Sufi sublime is a shade of this tendency; just as modernism has stripped Western societies of their ports of access to affective modes of being, the Sufi sublime is both an escape mechanism and a life-affirming infusion that offers what Kapchan calls the promise of sonic translation,

17 Mamdani's well-read premise in "Good Muslims, Bad Muslims" (Mamdani 2002) argues that the politicization of radical Islam is less an outcome of Islamic civilization than a product of its encounter with the West. Of particular interest is Mamdani's argument about the way "culture" and creative productions function within that encounter: "culture stands for creativity, for what being human is all about, in one part of the world, that [is] called 'modern,' but that in the other part, labeled 'premodern,' culture stands for habit, for some kind of instinctive activity whose rules are inscribed in early founding texts, usually religious, and mummified in early artifacts ... If the premodern peoples are said to lack a creative capacity, they are conversely said to have an abundant capacity for destruction. This is surely why culture talk has become the stuff of front-page news stories. It is, after all, the reason we are told to give serious attention to culture. It is said that culture is now a matter of life and death" (p. 767).

18 See, for example, Schmidle (2008). See Schimmel (1975) for a comprehensive view of Indo-Persian Islamic mysticism; see Ernst and Lawrence (2002) for an excellent assessment of the ideological and practical aspects of Chishti Sufism in particular.

19 I am thinking particularly of the rise of nativism in the US in recent years, encouraged by discourses circulated by President Trump and his allies. The Brexit movement in the UK has been motivated by a similar nativist sentiment. 
or "the belief that music can translate affect across cultural and linguistic divides" (Kapchan 2008, p. 468). In her study of the Fes Festival of World Sacred Music, held annually in Morocco, Kapchan found that the festival was "deeply implicated in creating counternarratives to that of the Muslim as fundamentalist and terrorist", a function which the Sufi sublime similarly enacts. This stance has a particular resonance among South Asian diasporic audiences, who have, for a long time, looked to the heterogenous places of Sufi shrines as accommodating spaces, for people from a range of socio-economic and religious backgrounds. The Sufi sublime is a feeling, best communicated through the arts and most immediately, through musical genres such as qawwali. ${ }^{20}$

It is, therefore, tempting to read some qawwali-based productions that have been produced in the UK and the US in intervening years, between the World Music industry dispensation of these sounds, to the resounding after effects of terror-of-terrorism as state policy, as either (1) empty signifiers, the dust left over after the splitting of sounds from their sources in the way of R. Murray Schafer's schizophonia: ${ }^{21}$ the residue of a process that increasingly separates us from the state of "nature" that we are meant to be aspiring to return to; or (2) celebratory hodge-podge of a sort of inter-faith, elevating ideal that may or may not have any actual relationship to the Chishti Sufi practice of the subcontinent as it was, or as it is in the process of becoming. We are going to take a closer listen to the sounds and signifiers contained within versions of a very common qawwali, Man Kunto Maula. This is not one of the rare gems of the Sufi poetic corpus; it is, rather, the most heard, most common of qawwalis based on the text of a hadith and set to music by Amir Khusrau, the beloved disciple of saint Nizamuddin Auliya, and sung at the opening of each mehfil-e-sama' as a matter of course. ${ }^{22}$ The musical material of this song would be used as an invocation to the sama' session, an invitation to listen. The lyrics of the qawwali identify the line of secession, from the Prophet to his successor Ali, the spiritual touchstone for Sufis the world over. This tune is easily recognizable, and often repeated, and for the very abundance of renditions, I have chosen to study it in a bit more detail.

\section{Man Kunto Maula in the Transnational Listening Space}

Since qawwali first entered transnational flows, marked by tours of the Sabri Brothers in the 1970s, and later with the superstardom of Nusrat Fateh Ali Khan and Abida Parveen, the musical genre has held pride of place in the sonic landscape of these outposts of postcolonialism. Outside the subcontinent, the music has been particularly resonant in the UK and US, and as recent generations of diasporic South Asians have grown up both here and there, and neither here nor there, the music has resonated with them. Likewise, the elements of the musical ensemble and the levels of sonic expertise and studio production have evolved alongside the listening experience. First, we will take a look at some exemplars of this qawwali. In the following section, we will look more closely at how one South Asian diasporic qawwali group based in Texas conceives of the work it is performing socially as it performs musically for American audiences. The section will take stock of the ways qawwali has moved from being a genre characterized by a primarily textual mode of signification to a largely sonic one in diasporic spaces.

20 One could argue that the intensity musically transmitted by qawwali practitioners, and the ecstatic states that often result from attentive Sufi listening, would not qualify as "sublime"; repeatedly, however, in pop culture representations of qawwali and other Sufi musical practices, there is an intentional cultivation of the transcendental.

21 This term originally appears in The New Soundscape (Schafer 1969). See Feld (1995) for a discussion of debates around technological anxiety in relation to the world music phenomenon and an appraisal of the literature related to "world music" from a mid-90s perspective.

22 See Qureshi (1986, pp. 20-22) for a detailed musicological analysis of the way this qawwali is used in the traditional setting of the Nizamuddin dargah. "This is the basic ritual song of Sufism in India; indeed one can call it the Opening-or Closing-Hymn of Qawwali. At Nizamuddin Auliya no Qawwali event can start any other way, while elsewhere in India and Pakistan the Qaul serves as a conclusion. The hymn expresses a basic Sufi tenet, that the principle of spiritual succession in Sufism was instituted by the Prophet himself, as recorded in one of his sayings (hadis)" (Qureshi 1986, p. 21). 


\section{Who Can Sing This Song? Listening in Diaspora}

Questions about repertoire, cultural ownership, and identity/identification have been on the minds of cultural analysts for some time now, particularly at the outposts of postcolonial empire. This nexus of concerns raises questions about who has access to music such as qawwali-who can legitimately sing this song? Must one be a male qawwal associated with the Chishtiyya lineage in order to produce a version that is authentic? ${ }^{23}$ What role do aesthetics have to play in the matter? There is a bit of a tug-of-war detectable in discourses within the dargah community, and in the concentric spheres of listeners attuned to this music, progressively on the outskirts of belonging. Even in the absence of clear answers, it is worthwhile to consider the conversations and the stakes involved in having them. For the bearers of this tradition, there is not just a cultural value and pride in the sense of ownership, but an economic dimension that bears consideration. Survival, prestige, and economic support are factors in this historical moment, when the analog, material lifeworld that generated the musical form has been inundated by the demands of the digital information sphere, and where the vestiges of a feudal model of economic support still remain. However, a sustained analysis of the economics of cultural survival are deserving of their own thorough consideration, beyond the scope of the present paper even as cultural value is a consideration.

Much like the circulation of bhangra ${ }^{24}$ in diaspora, qawwali has acquired new resonances in transnational contexts; Gopinath notes that

Bhangra, a transnational performance of culture and community, reveals the processes by which multiple diasporas intersect both with one another and with the national spaces that they are continuously negotiating and challenging. The diasporic web of "affiliation and affect" (Gilroy, Black Atlantic 16) that bhangra calls into being within and across various national contexts displaces the "home" country from its privileged position as originary site and re-deploys it as but one of many diasporic locations (Gopinath 1995, p. 304).

When it comes to questions related to diasporic iterations and transformations of musical style, as Gopinath affirms, the lens must shift to models accommodating of more complex structures than linear models of transmission; analysis becomes a matter of systems thinking and detecting the interlocking flows of multiple diasporic networks.

There are as many musical renditions of Man Kunto Maula, after centuries of circulation, as there are poems in the Sufi corpus. A comparison of versions of Man Kunto Maula tells us something about the way qawwali music has made its impression, circulated, and been transformed. The renditions range from careful explorations of the intricacies of raag (melodic mode), spiced with tarana, ${ }^{25}$ with intricacies of pacing and taal (rhythmic mode), to the glitterati-flushed versions of Coke Studio. One might point to Aziz Mian's version ${ }^{26}$ as traditional and functional: the pace is plodding, it is text-focused, repetitive, and almost shouted; the melody is unadorned and works for the purpose of delivering the message of the poetic text. While Mian is considered something of a rebellious figure in the qawwali landscape, as he is known to have inspired frenzied responses during his peak as a performer, he is a traditional qawwal in the sense that his focus is on the textual content of the song; he was himself a poet.

23 I recall, for example, having a debate with a professor during my undergraduate years, who claimed unequivocally that a version of Man Kunto Maula sung by Abida Parveen could not be considered qawwali based on her gender. She is often considered a performer of sufiana kalam, a related folk genre-see Abbas (2002, p. 4) for discussion. There are indeed other musical indicators in her performance that depart from the conventions of qawwali, which will be discussed below.

24 Bhangra is a folk music from the Punjab region of India and Pakistan. Since the 1980s, it has had a strong presence within diasporic spaces, particularly in the UK and US, as a form of popular dance music largely due to the driving rhythm of the dhol drum, which characterizes both the folk and popular forms of the music.

25 Tarana is a musical composition, often appended to a qawwali, based on phonemic sounds from Arabic and Persian words and is said to be among the many musical innovations of Amir Khusrau.

26 (Mian n.d.). 
The qawwal bacche ${ }^{27}$ of Nizamuddin dargah on a typical Thursday evening would offer a delivery that is similarly text-focused; there is an artistry in the way shers, poetic couplets typical of the ghazal form, and girahs, textual "knots", are introduced into a performance. Girah lagana, meaning "to tie knots", is the art of textual improvisation practiced by experienced qawwals, in which thematically related poetic material is drawn together in ways that may elicit a state of emotional arousal in the listener. While textual focus is paramount in this traditional qawwali setting, the influence of a concertized form of qawwali is evident in the melodic adornments now commonly incorporated into qawwali sessions at the dargah. Qureshi's (Qureshi 1986) seminal work on qawwali is focused on the structure and meaning of the traditional performance setting of the qawwal bacche; it typically emphasizes text over melody or sound, more broadly.

Departing from that center, then, we have the Sabri Brothers version, which is a classically informed, concertized rendition; they are remembered as among the most skilled performers of qawwali, and although not from a hereditary qawwali background, they do come from a highly musical one. Ghulam Farid Sabri, one of the two brothers who led the original group, was a dedicated Sufi murid, or disciple. The version delivered by the Sabri Brothers ${ }^{28}$ is highly refined, with an extended alap-like ${ }^{29}$ introduction. It is the most classical sounding of the collection here; departing from the Sabri Brothers version, the renditions move away from the model of text-centered, poetry-based compositions and become increasingly aestheticized.

Nusrat's version ${ }^{30}$ is characterized by an extended introduction on the harmonium, followed by an exploratory alap, which establishes raag Bhupali one note at a time, and utilizes the text in much the way a more classical khyal bandish ${ }^{31}$ would: by breaking it down into parcels of conjoined phonemes and toying with them in ever more innovative ways. Through NFAK's vocal calisthenics, this sonic play then segues into the tarana section of the composition, a trance-inducing segment on "dar-a-dil-le"; this is meant to push the listener over the edge, through the disciplined bodily control of daily comportment, toward states of ecstasy. The delivery is masterful, jaunty, although it never leaves raag Bhupali until 13 and a 1/2 minutes in, when one of the party singers introduces a hint of raag Yaman, which is commonly associated with this qawwali but is not explored in depth here.

There is no voice like Nusrat's voice; with a six-octave range, he could cover a lot of ground. The clarity of his tone, particularly in the upper registers, is a revelation. His voice sounds the translucence of amber, with an agility that no other qawwal before or since has been able to replicate. One can hear the story of qawwali unfold from his voice as if from a scroll unfurling. He was on the edge of innovation within the genre; while he took certain risks in the collaborations he explored and genre-transgressions he took part in, his sheer vocal skill and mastery within the genre has allowed him to retain his status as unrivaled king of qawwali. His impact continues to resound across the globe, wherever listeners are attuned; whereas groups such as the Sabri Brothers had preceded his arrival in the West, the impact of NFAK has been much wider and more profound.

Abida Parveen's version, ${ }^{32}$ on the other hand, is pure affect; if the rugged earth could sing, I imagine this is how it would sound. The particular grain of her voice, the way it conveys an internal resonation, echoes within the valley of itself. Her voice throws open the floodgates of feeling, stirs something beneath the layers of daily accumulation, cracking open a pathway to rooh, the Sufi notion of embodied spirit; her voice makes manifest the realm of ultimate truth, haq or haqiqi, which is Allah's

27 The qawwal bacche are descendents of Amir Khusrau's original group of qawwali performers, who are said to have been trained as a gift to his pir, or spiritual guide, Nizamuddin. The bacche have been providing musical support at the Nizamuddin dargah for centuries. See Qureshi (1986) for further discussion.

28 (Sabri Brothers n.d.). Man Kunto Maula, concert recording posted by Basheer Ahmed Nizami.

29 Alap is the improvisatory introduction to a raag, which establishes the contours and character of the melodic mode.

30 (Khan 1992).

31 Khyal (or khayal) is a prominent Hindustani classical vocal form; bandish is a fixed composition with defined poetic, melodic, and rhythmic components.

32 (Parveen 2001). 
alone. Somehow, she sings those unseen realms into our ears; she is that attuned. Like Nusrat, she is a master of intonation; however, she uniquely emphasizes both text and timbre in her delivery. Typically regarded as a singer of sufiana kalam, in her version, musical elements atypical of a qawwali party format—cymbals, driving taal, and a more folk-oriented style of harmonium usage-are present. The composer John Tavener said he had a "gut-wobbling, primordial experience watching her in rehearsals for their one-off show together" ${ }^{\prime 33}$. Just as she impacts the listener on that "gut wobble" level, her global impact is difficult to overstate.

From these two exemplars, many musical projects have sprung. There is a qawwali jazz band in Brooklyn that only plays NFAK's standards. A trend within India has seen vocalists from a wide range of backgrounds take on what Rahaim calls "singing Sufi"34. Abi Sampa's audiovisual version ${ }^{35}$ is melodically close to the original, while also being a truly diasporic affair-a mashup of styles and signifiers that could be the soundtrack to the Sufi sublime. A UK-born singer who first gained visibility as a contestant on the UK's The Voice, the first of South Asian descent to be featured on the show, she is also a veena player. Her version is a sonically crisp, highly-produced studio recording. One notices firstly her timbre: it is husky, like a port cellared for a while; this is not your mom's playback singer, nor is it qawwali of the traditional sort. A dancer, Vidya Patel, dons robes reminiscent of a Mevlana, the Turkish whirling dervish of the lineage descending from Rumi's followers; her movements are stylized and influenced by modern dance.

The ensemble has acquired a guitar and a set of string players of a gradient of brown hues; there is a pride, now, in the visible markers of difference. Breathy even as it pours forth texture, Sampa's voice is transcontinental, transcendental. This is a pan-South Asian, gender-bending rendition: the vocalist, dressed in resplendent finery reminiscent of a Bollywood spectacle, skillfully ornaments her vocal line, but in an expected way; it is more studied than improvisational. Still, though it would be simpler to write this off as just another pop song, in this era of rising nationalism at multiple points in the diasporic web, this work strikes me as important. It says: our culture is not only beautiful in the way that is dusty, on a museum shelf for someone's viewing pleasure. It says: we can take the materials, in this case sonic, of a long-lived cultural formation and re-purpose the signifiers in ways that are meaningful to us, and likewise meaningful to others. These are windows into who we are, and we belong here. This is a visual elaboration of the traditional purely auditory form; it is more Bollywood than Nizamuddin, but there is a real grit in her voice that somehow speaks volumes.

In a traditional qawwali sama' setting, echoes of South Asia's feudal past are still resounding; these are clear in the relationship of qawwali to listening publics. The qawwal bacche are, according to Qureshi's study, servants of the shrine community, and this is an honorable function; there is very little of the star quality in it. This star mentality enters qawwali performance spaces in conjunction with its uptake into the sonic landscape of Bollywood and the concert stage and then into the flow of World Music. Once that sonic flow enters the diasporic network, qawwals gain a metaphorical sort of voice, an individualized one that they had not possessed before. He/she (because here, gender is more fluid) becomes heard in a new way, elevated because the West loves a star. No longer a feudal subject, these tinges of stardom cycle back and fold in upon the culture of performance at the shrine complexes as well. There is a dialogic element to the way this works.

The further one moves from the center of the tradition, the scaffolding upon which processes of improvisation are built become less sturdy; in Abi Sampa's version, while she delivers a stunning rendition, it is much more fixed than the hereditary qawwals' versions would be; and it is polished to a sonic shine. In the shrine context, we hear improvisation on a textual level, while on the concert stage, it appears in forms of melodic development characteristic of the Hindustani classical vocal

\footnotetext{
(Iqbal 2013).

(Rahaim 2020).

(Sampa 2020).
} 
genres. At this stage in diaspora, improvisation appears in other guises. Noticeably, in Sampa's version, we have a great deal more flexibility with gendered access and representation. As a literary device, the feminine voice has often been used to convey feelings of longing for God through the embodied voices of qawwals. ${ }^{36}$ However, until recently, an embodied woman would not sing them, not qawwali, in any case. Sufiana kalam has for some time largely been the purview of female folk singers (Abbas 2007). What occurred with the rise of Abida Parveen was a de-linking of embodied gender and access to this genre; she was among those transnational voices that gave permission to other female singers both to take on the qawwali repertoire and also to sing in a deep alto range. ${ }^{37}$ It is, in short, both the sonic material of the song and also its gendered representations that have been transformed in the range of performances that we witness in diasporic settings. Let us turn now to Riyaaz Qawwali, to see how they are enacting another sort of transformation of musical material in diaspora.

\section{Riyaaz Qawwali: Being/Becoming an Instrument}

As the camera rolls, an elder Sardarji waves his Chaur Sahib, a ceremonial whisk, fanning the Guru Granth Sahib, the sacred book of the Sikh faith. The sepia of the video gives a sense that we are in a classic Bollywood scene, from a half century ago; the patina is somehow both anachronistic and timeless. "Koi Bole Ram Ram"38 is a 2010 video recording of Riyaaz Qawwali singing a Shabad kirtan, or Sikh devotional hymn, performed in qawwali style. It is one among a number of unusual choices for the qawwali repertoire recorded by the group-religious songs that come from outside the tradition rendered in qawwali style.

While prominent musicians such as the Sabri Brothers and later Nusrat Fateh Ali Khan exposed audiences in the West to the sounds of qawwali, in recent years, non-hereditary groups of musicians based in the US have begun to perform this repertoire (Rashid 2017). One such group, Riyaaz Qawwali, based in Texas and comprised of South Asian musicians from a range of geographical, religious, and political orientations, has become a noted presence within the US South Asian diasporic soundscape. ${ }^{39}$ The group's make-up is heterogeneous: although all members are from a South Asian background, their ties are to different states, ethnic/linguistic groupings, and religious identifications. Because of their internal diversity, Riyaaz Qawwali is an apt representation of the diversity of the most recent wave of migration from South Asia to the US. ${ }^{40}$ Riyaaz Qawwali has a more local orientation-that is, national rather than international-than some of the previously mentioned performers; even as Riyaaz's recordings are available widely on platforms such as YouTube and Spotify, their sustenance is live performance; they appear widely at world music venues, particularly at South Asian cultural events, within the US-in their home state of Texas, and other urban centers such as New York City, Philadelphia, and the SF Bay Area. They have not, to date, toured in India, but they have performed in Europe and Latin America, and they see themselves collectively as a voice that speaks to, and is representative of, the diversity of the South Asian diasporic population within the US.

36 See Abbas (2002) for an extended exploration of the way the feminine voice has been used as a literary device in Sufi musical settings.

37 The aesthetic that had been the vogue in South Asian auditory spheres since the playback singer Lata Mangeshkar's sound shaped the sonic ideal of the Indian female singing voice was upper tessitura; see Sundar (2008) for a close analysis of Mangeshkar's impact.

38 (Riyaaz Qawwali 2010).

39 The other such notable group is Fana Fi Allah, a group comprised of Canadian-Californians. The members of the group have worked closely with Dildar Hussein, the tabla player for NFAK's qawwali party.

40 Generally, these waves are conceived in three stages: the late early 20th century migrants who came from the community of Punjabi Sikhs to work the railroads in the Western US; the mid-60s to 1990, with generally high-skilled engineers, small business owners, and other professionals; and most recently, from the 1990s, a more heterogenous group consisting of a wider range of ethnic, socio-economic, and professional orientations. See Hedge and Sahoo (2018) for more on the dynamics of Indian diasporic movement over time. 
Riyaaz Qawwali performs in the style of qawwali, with the sonic markers of the genre. While Sufi milieus within South Asia are idealized as geographical sites of a communal harmony, Riyaaz has sonified this principle-stretching the boundaries of the qawwali repertoire by incorporating songs associated with a variety of religious orientations, such as Sikh Shabad mentioned above and Hindu bhajans; Riyaaz deftly transmutes them into qawwali compositions. It is not unheard of for performers outside the religious practice to perform qawwali; neither is it unusual to hear references to Hindu festivals and cultural themes such as Holi, the pivot point at which the common ideas about Divine love cross borders between religions. However, Riyaaz does this in a way that is novel, as it is not just thematic content, but well-known songs with strong associations to other religious traditions that Riyaaz seamlessly renders in qawwali style. Vaishnava Jan To is one such song; consistently associated with Gandhiji, this Gujarati bhajan is rendered as a qawwali by the group.

Their first album release is called Kashti, meaning boat. The group envisions their work in this way, as a sonic ferry that metaphorically crosses the gulf between religious ideologies. Sonny is a vocalist who was touched early in his life by the music of NFAK; he notes that in the US, as he was coming of age as a singer, "the canvas was such that qawwali no longer had a Nusrat Fateh Ali Khan, riding around the world lighting people on fire". Khan's passing in 1997 meant that "people were not experiencing the magic"; that lacuna was a motivating factor for Sonny, who eventually pursued qawwali performance as a profession. When I ask him why he chooses to do qawwali as a conscientiously interfaith project, he elaborates that

"Qawwali has a richness that makes me feel more alive than I ever do ... that I need to share. So, to me, the idea was to share qawwali with as many people as possible. And as I started doing that, I started realizing you need to [convey] the ishq-a-haqqiqi, ishq-a-majazi, ${ }^{41}$ the love that's dual. But then, for them to really feel the ras, the nectar of Sufi devotion, you need to go a little bit into their space as well"' (Personal Interview, 8/27/20).

Sonny sees that the South Asian population within the US is made up of a diverse set of people, holding a range of beliefs and nested identities. In order to reach them, he has chosen to focus on this act of bridge building, to reach as many listeners as possible. Sonny is clear in his intention: it is an ecumenical one. When I raise concerns about what it means to perform a song such as Vaishnava Jan To, which is associated with Gandhiji, one of the key figures of the Indian independence movement who has, more recently, been appropriated as an icon of the Hindutva movement, he is clear that the chronology of the group's efforts predates this current rightward swing within Indian politics. The work Riyaaz is doing is to foster connections between the diverse South Asian immigrant population in the US, rather than to assert the prevalence of a single religious group.

Among the key artistic drivers in the US is the flexibility that is enabled by being outside the center of the tradition. "There's a level of collaboration that is possible here that would be more difficult in India", Sonny says, and this, it is implied, is for a number of reasons. The structures of tradition - both of the qawwali form and also the performance and listening cultures associated with it-are long established, with a more fixed set of functions and expectations, at the center of the practice. He sees the work of the group as being oriented toward the diaspora specifically, and this requires a greater degree of flexibility in order to appeal to a broad listening public. Still, I am curious about how the group decides which songs will be transformed into qawwalis. When I ask what his process for choosing is, he replies that certain songs lend themselves to be rendered in a qawwali style. "They sort of choose themselves", he says. "It's not an intellectual practice. I come from the belief that faith, and God, talks through people. I believe that whether I'm praying to Allah, or Ram, or Christ, to me

41 This is the characteristic tension between Divine (haqiqi) and worldly (majazi) love that is the foundation Sufi ethics is built upon, and through which an allegorical, affective model of devotion is crafted. 
there's no difference. And maybe that's part of what's created this khichdit2 of an ensemble that is Riyaaz Qawwali". There is an attunement and receptiveness that underlie the creative process; this in turn allows for innovation.

He continues, "You love the work. And then you become an instrument of it". He acknowledges that occasionally, the product can be of low quality; other times, though, magic happens, and that, he says, is what makes the whole endeavor worthwhile. "I do believe in my heart of hearts that sometimes this innovation comes through-when I sing it, and I listen, I'm moved by it. Yahan pe kuch hai, there's something here, and so we build on that". That unknown, ineffable spark that allows a creative act to gel-for a work to take on a life of its own - is an element of the creative process that Sonny experiences. In another instance of becoming an instrument, he recounts the story of performing at the Philadelphia Ganesh Festival. He says, "There were some folks in the Hindu community who said 'oh, now you've become Muslim.' Yet, in the concert, we were excited to present them a qawwali to Ganesh. Gaiye Ganpati was a tune that was somehow in my head, and it just developed as a qawwali. We put in some work, and brought it to the audience, and it really moved them". Hearing about this event, I was struck by the way tensions between group identities can flare up and become resolved in diasporic settings; even as suggestions of communal infidelity were leveled, they were quickly resolved through the hybridized performance. Meanwhile, actual state-sponsored discrimination against Muslim-Americans has flared up at multiple points since 9/11. While vestiges of the firm boundaries between ethno-linguistic identifications remain in diaspora, this music has a unifying function. Perhaps an aspect of the instrumentalism of a group such as Riyaaz Qawwali in the diasporic setting is this: smoothing the rough edges of potential conflict between these identifications; this seems important cultural work in our historical moment.

At the same time, this sort of instrumentalism has something of the star quality in it; it foregrounds the innovative/creative work of the performer, which contrasts with the traditional qawwal's function within a sama' assembly. Huda (2007) notes that "The Qawwali poetry in itself, when sung, strives to bring a spiritual experience that transcends the norms of daily living. The Qawwali singer is merely an instrument who attempts to use the poetry as a device to kindle the flame of love, and, for the most part, to intensify the longing for a mystical union" (p. 682). Notably, at the center of the qawwali practice, the instrumentality of the qawwal's work is to kindle feelings of love that connect the listener with the Divine Beloved; the performer in this setting remains de-centered in a way that would not be viable in a Western performing arts context. The unifying impulse that drives Riyaaz Qawwali's work is operative and effective in the diasporic setting; still, I wonder whether there are risks involved with presenting Hindu songs in qawwali style; while certainly not the group's intent, this move could be interpreted as echoing Hindu narratives of inclusivity, which have tended to subsume minority groups in processes of encompassment. Politically, the repercussions of this process can appear quite like elimination by embrace.

\section{Conclusions}

The textures of the Indian diaspora are, in this third decade of the 21st century, variegated and diverse; extending in dense networks across the globe. During the era of Empire, labor demands created both opportunities and forms of indenture for Indians, opening flows of migration to distant outposts. More recently, migration patterns have tended to shift back toward the centers of former empire and have often involved shades of the "brain drain" phenomenon; these patterns of return have created rich and heterogeneous social fabrics in these sites-including urban, cosmopolitan locales in the UK and US. The admixture of immigrant groups was not new in these locations in the post-WWII era; however, the speed at which populations began to move and resettle was novel,

42 Khichdi is a North Indian stew made of lentils, rice, ghee, and spices. The term is used colloquially to describe a mixture of things. 
and these demographic shifts have elicited reactionary responses, as tensions between migrants and the long-settled have sometimes boiled over. South Asian diasporic settlers have been viewed with simultaneous exoticism and suspicion; we have been othered in distinct ways on both landmasses, even though our influence-in ways including the culinary, sonic, and philosophical-has seeped in.

Early anthropological studies of diasporic cultural formations tended to focus on ways migrants kept their gaze affixed to the homeland: documenting efforts to preserve authenticity, reproducing social expectations, and re-presenting cultural practices that had been carried along migration routes like luggage. That relationship was interpreted as a linear, bi-directional flow-of migration and return, authenticity and reproduction —and sought to keep alive forms of cultural expression that were sometimes already historical at the point of origin. Appadurai's work (Appadurai 1996) reoriented the academic conversation around the profound impact media circulation was having on identifications of people and groups and the senses of self it was engendering. Appadurai's work continues to resonate with analyses of diasporic cultural formations even now, a quarter of a century later, as the impact of technological mediation has exceeded those early accounts; his analysis deterritorialized the migrant, popping the bubble of nostalgia that had encased diasporic memory and anthropological accounts thereof, and began instead to detect flows, of information and people, as they merged with and altered the textures of the -scapes of modernity. Hegde (2019) notes that "even as diasporas reproduce remembered traditions, traditions themselves are reconstituted in more portable forms in order to regain legitimacy in digital circuits ... diasporic groups fuse the past and present in innovative and resistant ways, producing new authenticities" (p. 227). We are seeing that these new authenticities emerge in sometimes unexpected forms.

This article has sought to highlight ways cultural formations in diasporic settings have shifted alongside the digital flows permeating the information sphere since the turn of the millennium. What Gilroy (1993) identified as the complex "web of affiliation and affect" shapes the ways diasporic identities are being recast through the prism of music in the contemporary cultural landscape. As Hegde (2019) observes, "diasporas ... trouble the meanings of the real and authentic and, of course, the enduring territoriality and fixity of cultural forms" (p. 227). While earlier generations held fast to authentic modes of expression, of both identities and cultural formations, younger generations-often children of immigrants in these outposts of post-colonial empire-are exploring means of refiguring these formations in ways that are neither authentic nor spurious, ways that may not be captured by simple models of hybridity. They are instead mobilizing the sonic materials of the central practice in order to mold those elements like clay, fashioning something novel in the process of their reinvention.

There is, of course, a tension between the intent and function of the traditional form of qawwali and these contemporary exemplars; diasporic artists who re-present this music do not often abide by the strictures of the practice as it is in its originary site. Liveness itself is an issue; the forms of improvisatory engagement with the corpus of the musical and poetic material is not reproducible outside of the circles of hereditary transmission, and the diasporic artists are not steeped in the tradition in the same way. The scale at which affective states are elicited and sung to in pursuit of a spiritual goal cannot be reproduced in diasporic locations. Yet, it would be a mistake to say these versions, particularly the pop-oriented one, are mere mechanical reproductions.

These artistic moves are not ultimately fixated on the homeland; they do not intend to lay claim to identities that may be removed by a generation or two at this historical point. Digital flows introduce cultural forms that have morphed as they have traveled. The mediated-ness of the data, de-linked from the immediacy of live performance, is apparent; however, there is something else evident in the Sufi sublime. Rather than re-instantiating a sense of authenticity, it is performing two specific functions that I can detect: firstly, to stake a claim in the new territory, not as migrants and also not as Others intending to assimilate, but in a way that carves out a third space, which thrives at the interstices by mobilizing the materials of the original practice in creative and affective ways. The second function is to stitch a sonic fabric that links people of diverse regional, linguistic, and religious orientations into a group that has become linked, if not unified, in diaspora through listening practices. 
The two insistently diasporic artists highlighted in this article, Abi Sampa and Riyaaz Qawwali, take distinct approaches to qawwali performance. Riyaaz Qawwali is, to my ear, the most sonically attuned to the genre. Even as the group takes risk and innovation in new directions, they remain true to a number of the ideals of Sufism of the South Asian variety: their embrace of the esotericism at the heart of the philosophy, the consonance with a pluralist religious orientation, and the savoring of the poetic heritage that characterizes Indo-Muslim cultural forms. Riyaaz Qawwali shies from engaging with qawwals at the center; I gathered that this was because they understand their spirituality to be unmoored from the Sufi practice in favor of more personalized forms of devotion. Riyaaz's efforts, like Sampa's, are very much oriented toward "locating a space within the national culture, thereby disrupting and redefining the very nature of that culture" (Gopinath 1995, p. 313).

Sampa's version of Man Kunto Maula leans into the aesthetic signifiers of the genre, while disrupting gendered and religious conventions. Her "qawwali orchestra" is defiantly heterogenous, with every religious identification represented, incorporating instrumentation that is a unity of East and West. It is not attempting to re-produce or even converse with the original form, and that could be noted as problematic. At the same time, it is insistent on its ability to reshape the cultural material of the qawwali. Significant here is the notion that, in the moment when Hindutva governance has led to rising anti-Islamic sentiment within India, cultural forms of Sufi expressivity have come to stand in as a catch-all form of spiritual identification within the diaspora. This Sufi sublime has very little to do with actual Sufi practice, and it is my sense that, from the perspective of dedicated Sufi adepts, this rendition would not be meaningful: it is aestheticized beyond recognition; it no longer performs its function as a call to the spiritual listening assembly; the framework for semantic improvisation is absent; and the goal of inducing states of emotional arousal and ecstatic communion with God is no longer the preeminent aspect of the performance. However, it also should not be written off as mere pop drivel. It is beautifully produced, sonically lush, and deeply affective from the perspective of the diasporic listener. The meaningfulness of this version lies in its ability to mobilize sonic signifiers that hearken to this state of spirituality; it elevates the Sufi ideal, even as it skirts the rigor of dedication and practice. Most importantly, it carves out a space within the new land for this population to exist, on its own terms and with its own voice.

Funding: This research received no external funding.

Acknowledgments: The author is grateful to Anna Stirr for the invitation to contribute to this special issue and to Pir Khwaja Afzal Nizami, Sufi Syed Ajmal Nizami, and Sonny Mehta for sharing their time and stories.

Conflicts of Interest: The author declares no conflict of interest.

\section{References}

Abbas, Shemeem Burney. 2002. The Female Voice in Sufi Ritual: Devotional Practices of Pakistan and India. Austin: University of Texas Press.

Abbas, Shemeem Burney. 2007. Risky Knowledge in Risky Times: Political Discourses of Qawwali and Sufiana-kalam in Pakistan-Indian Sufism. The Muslim World 97: 626-39. [CrossRef]

Appadurai, Arjun. 1996. Modernity at Large: Cultural Dimensions of Globalization. Minneapolis: University of Minnesota Press.

Barthes, Roland. 1977. The Grain of the Voice. In Image, Music, Text. New York: Hill and Wang.

Eidsheim, Nina Sun. 2015. Sensing Sound: Singing and Listening and Vibrational Practice. Durham: Duke University Press. Eisenlohr, Patrick. 2018. Sounding Islam: Voice, Media, and Sonic Atmospheres in an Indian Ocean World. Oakland: University of California Press.

Erlmann, Veit. 1996. The Aesthetics of the Global Imagination: Reflections on World Music in the 1990s. Public Culture 8: 467-87. [CrossRef]

Ernst, Carl, and Bruce Lawrence. 2002. Sufi Martyrs of Love: Chishti Sufism in South Asia and Beyond. New York: Palgrave Macmillan. 
Feld, Steven. 1995. From Schizophonia to Schismogenesis: The Discourses and Practices of World Music and World Beat. In The Traffic in Culture: Refiguring Art and Anthropology. Edited by George E. Marcus and Fred R. Myers. Berkeley: University of California Press, pp. 96-126.

Funes, Maria Eugenia. 2016. Neoliberalism and New Age. In Encyclopedia of Latin American Religions. Online: Springer. [CrossRef]

Gilroy, Paul. 1993. The Black Atlantic: Modernity and Double Consciousness. Cambridge: Harvard University Press. Gopinath, Gayatri. 1995. 'Bombay, U.K., Yuba City': Bhangra Music and the Engendering of Diaspora. Diaspora: A Journal of Transnational Studies 4: 303-21. [CrossRef]

Hegde, Radha S. 2019. Scripting Indianness Remediating Narratives of Diasporic Affiliation and Authenticity. In The Handbook of Diasporas, Media, and Culture. Edited by Jessica Retis and Roza Tsagarousianou. Hoboken: John Wiley \& Sons, Inc., pp. 225-38.

Hedge, Radha S., and Ajaya K. Sahoo. 2018. Introduction. In The Routledge Handbook of the Indian Diaspora. Edited by Radha Sharma Hedge and Ajaya Kumar Sahoo. London: Routledge, pp. 1-14.

Huda, Qamar-ul. 2007. Memory, Performance, and Poetic Peacemaking in Qawwali. The Muslim World 97: 678-700. [CrossRef]

Iqbal, Nosheen. 2013. Abida Parveen: 'I'm not a man or a woman, I'm a vehicle for passion'. The Guardian, July 8. Available online: https://www.theguardian.com/music/2013/jul/08/abida-parveen-sufi-singer-passion (accessed on 20 December 2020).

Kapchan, Deborah A. 2008. The Promise of Sonic Translation: Performing the Festive Sacred in Morocco. American Anthropologist 110: 467-83. [CrossRef]

Khan, Nusrat Fateh Ali. 1992. Mann Kunto Maula. Available online: https://www.youtube.com/watch?v= KtvnJhdQLJY (accessed on 20 December 2020).

Lewisohn, Leonard. 1997. The Sacred Music of Islam: Sama' in the Persian Sufi Tradition. British Journal of Ethnomusicology 6: 1-33. [CrossRef]

Mamdani, Mahmood. 2002. Good Muslim, Bad Muslim: A Political Perspective on Culture and Terrorism. American Anthropologist 104: 766-75. [CrossRef]

Manuel, Peter. 2008. North Indian Sufi Popular Music in the Age of Hindu and Muslim Fundamentalism. Ethnomusicology 52: 378-400.

Mian, Aziz. n.d. Man Kunto Maula. Available online: https://www.youtube.com/watch?v=ZESaVEHVJxI\&t=891s (accessed on 20 December 2020).

Parveen, Abida. 2001. Man Kunto Maula. Available online: https://www.youtube.com/watch?v=ybxYX1lehg8 (accessed on 20 December 2020).

Qureshi, Regula. 1986. Sufi Music of India and Pakistan: Sound, Context and Meaning in Qawwali. Cambridge: Cambridge University Press.

Qureshi, Regula. 2000. How Does Music Mean? Embodied Memories and the Politics of Affect in the Indian sarangi. American Ethnologist 27: 805-38. [CrossRef]

Qureshi, Regula Burckhardt. 1999. His Master's Voice? Exploring Qawwali and 'Gramophone Culture' in South Asia. Popular Music 18: 63-98. [CrossRef]

Rahaim, Matt. 2011. That Ban(e) of Indian Music: Hearing Politics in The Harmonium. The Journal of Asian Studies 70: 657-82. [CrossRef]

Rahaim, Matthew. 2012. Musicking Bodies: Gesture and Voice in Hindustani Music. Middletown: Weslyean University Press.

Rahaim, Matthew. 2020. Singing 'Sufi' Secular. Paper presented at the SEM 2020 Virtual Annual Meeting, Online, October 22-31.

Rana, Muhammad Amir. 2008. Counter-ideology: Unanswered Questions and the Case of Pakistan. Perspectives on Terrorism 2: 3-5.

Rashid, Hussein. 2017. Qawwali in America: Making Space. The Muslim World 107: 271-86. [CrossRef]

Riyaaz Qawwali. 2010. Koi Bole Ram Ram. Available online: https://www.youtube.com/watch?v=CX2zwHjXgrI (accessed on 20 December 2020).

Rozehnal, Robert. 2007. A 'Proving Ground' for Spiritual Mastery: The Chishti Sabiri Musical Assembly. The Muslim World 97: 657-77. [CrossRef]

Sabri Brothers. n.d. Man Kunto Maula. Available online: https://www.youtube.com/watch?v=8QLH3d8BXuQ (accessed on 20 December 2020). 
Sampa, Abi. 2020. Man Kunto Maula. Available online: https://www.youtube.com/watch?v=WyZZBpxcLMw (accessed on 20 December 2020).

Saniotis, Arthur. 2012. Attaining the Mystical Body: Indian Sufi Ascetic Practices. The Australian Journal of Anthropology 23: 65-83. [CrossRef]

Schafer, R. Murray. 1969. The New Soundscape: A Handbook for the Modern Teacher. Don Mills: BMI Canada Ltd. Schimmel, Annemarie. 1975. Mystical Dimensions of Islam. Chapel Hill: The University of North Carolina Press.

Schmidle, Nicholas. 2008. Pakistan's Sufis Preach Faith and Ecstasy. Smithsonian Magazine. Available online: https: //www.smithsonianmag.com/arts-culture/pakistans-sufis-preach-faith-and-ecstasy-92998056/ (accessed on 20 December 2020).

Slobin, Mark. 1992. Micromusics of the West: A Comparative Approach. Ethnomusicology 36: 1-87. [CrossRef]

Stokes, Martin. 2003. Globalization and the Politics of World Music. In The Cultural Study of Music: A Critical Introduction. Edited by Martin Clayton, Trevor Herbert and Richard Middleton. London: Routledge, pp. 297-308.

Sundar, Pavitra. 2008. Meri Avaaz Suno: Women, Vocality, and Nation in Hindi Cinema. Meridians 8: 144-79. [CrossRef]

Sundar, Pavitra. 2017. Romance, Piety, and Fun: The Transformation of Qawwali and Islamicate Culture in Hindi Cinema. South Asian Popular Culture 15: 139-53. [CrossRef]

Vajpeyi, Ananya. 2009. The Indo-Persian Sublime. Wasafiri 24: 36-46. [CrossRef]

Weidman, Amanda. 2006. Singing the Classical, Voicing the Modern: The Postcolonial Politics of Music in South India. Durham: Duke University Press.

Publisher's Note: MDPI stays neutral with regard to jurisdictional claims in published maps and institutional affiliations. 